\title{
Implementation of Operational Strategy Planning in Doku Application
}

\author{
Selfi Rizky Handayani ${ }^{1}$, Rhian Indradewa ${ }^{2}$, Tantri Yanuar Rahmat $\mathrm{Syah}^{3}$, \\ Edi Hamdi ${ }^{4}$ \\ ${ }^{1,2,3,4}$ Department of Management, Faculty of Economics and Business, Esa Unggul University, Jakarta - \\ Indonesia \\ Corresponding Author: Selfi Rizky Handayani
}

\begin{abstract}
Background - Health services are one of the most widely used public services, administered by BPJS Health reaching 222.5 million people as of December 31, 2020. This figure is equivalent to $81.3 \%$ of the total population in Indonesia. The Doku application is an application that will help level I Health Facilities and Hospitals to manage BPJS patient services. The Doku application will replace the conventional BPJS patient services at Level I Health Facilities and Hospitals to online. This business opportunity is quite large, even though there are threats from existing applications, with more brands and users, but based on the results of QSPM is product development strategy; Doku will always update features and add according to market needs.
\end{abstract}

Method - Product design operational management approach

Result - This product design helps companies to implement user requirements in the form of user interface.

Keywords: Application, Doku, Feature Update, Business opportunity

\section{INTRODUCTION}

Health services are one of the most widely used public services. Badan Penyelenggara Jaminan Sosial (BPJS) is a government service center established to administer the National Health Insurance, BPJS participants are mandatory for workers in the formal and informal sectors, the number of participants for Jaminan Kesehatan Nasional (JKN) program organized by BPJS Health reaches 222.5 million people as of December 31, 2020. This figure is equivalent to $81.3 \%$ of the population in Indonesia (Andrea Lidwina, 2021). In the BPJS system, participants must first go through Health Facility I (puskesmas, general clinics, or family doctors) as the first place to provide health services. Hospitals do not yet have special technology to facilitate BPJS patient services. The Doku application will help level I health facilities and hospitals to manage BPJS patient services. The Doku application will replace the conventional BPJS patient services at clinic and hospitals to be online. In this era of increasingly advanced technology, the application industry can be developed and is a profitable business (Operations Strategy, n.d.). This application will integrate Hospital data to clinics.

\section{MATERIALS AND METHODS}

There are various ways and stages in running a business, here are the stages:

\subsection{Business Establishment Stages}

PT. Zaps Teknologi will be established in Harmoni Harapan Indah Ruko North Bekasi, with an area of $320 \mathrm{~m} 2$ for $55-$ 60 million/year. Surat Keterangan Domisili Perusahaan Usaha (SKDU) PT. Zaps technology can be obtained from the local village office. The founders of the company consist of four people, Zulham, Adi, Prima and Selfi. The number of founders has 
complied, according to the law the founders of the company must be more than two people. This location was is strategic to increase Doku's operational activities in the health industry because it is close to several local hospitals, making it easier for Doku to collaborate with external parties such as Eka Harapan Indah Hospital, Hospital Harapan Kita and Pusaka Rakyat Hospital (Ramadhan et al., 2020).

\subsection{Operational Strength}

There are already applications that have a similar concept. The Doku application is an online referral application in collaboration with hospitals, where patient data integration is carried out in clinics and hospitals. One of the advantages of this application compared to existing applications is that patients do not do anything including downloading applications. All will be served through the system and the user only needs to receive the final confirmation. This application will be integrated with SIMRS in every hospital. SIMRS will be integrated with the management of hospitals. Based on the results of the analysis of five porter force obtained a score of 1.32 which means that Doku company still has a large enough opportunity to develop business in this field (Robert_Grant, 2010)

\section{Operational Weakness}

Based on the analysis of the main weaknesses of doku applications, product Doku as a startup are still not widely known. Online referral theme has been widely used by several technology companies in developing their business ideas. As currently exists, the JKN application is an application belonging to the BUMN. One of Doku's weaknesses is brand awareness. When compared to JKN, of course Doku will lose, JKN is already famous. Then from a financial perspective, as a new start-up, large funds are needed to start this business and the limited number of resources requires high efficiency to achieve the company's targets. In principle, a limited liability company is a partnership, so the establishment of a limited liability company must be carried out by 2 or more people. The agreement is made by making a deed establishment with a notarial deed. Doku application investment is divided into three parts (1). Own funds (2). Bank loans (3). Investors (3rd year). pre-opening and postlaunch investment costs (Hardono et al., 2021). Pre-Opening Investment represents all initial costs incurred for the preparation process in the form of office rental and preparation for initial construction, which will initially use own funds. QSPM can be used to select the most suitable strategy to be applied in the company from various alternative strategies that have been formulated previously. (Ul Haq et al., 2020)

\section{DISCUSSION}

\subsection{Operational Design}

Management is an optimal form of management for various production factors of the company (Hardono et al., 2021) This means that operational management is a manager so that human resources, goods, equipment, machines, raw materials, and also other production factors can become services traded by document companies.

\subsection{High Level Architecture Design}

High Level Design describes the architecture that the document will use to develop the system. The architecture diagram provides an overview of the entire document system, identifying the main components to be developed for the document product and its interfaces.

Figure 1 is the. Described with three layers, each layer has a different function. The presentation layer is all the parts related to the presentation layer. Users can access the application through the website. The business layer is everything related to the business logic. The Doku application is an integration of various systems, starting from the API, modules consisting of the components required by the Doku application. The database layer is where all layer data is stored, doku uses two patient 
data databases to store all patient data information and a queue database. To make it easier for users to access the Doku application server, we share data centers in several areas in Jakarta so that internet data traffic is stable. It is fast and easy to access by users, and data center security does not need to be doubted because it uses many firewalls. For backup, database will maintained in everyday.(Yanuar Rahmat Syah et al., 2021)

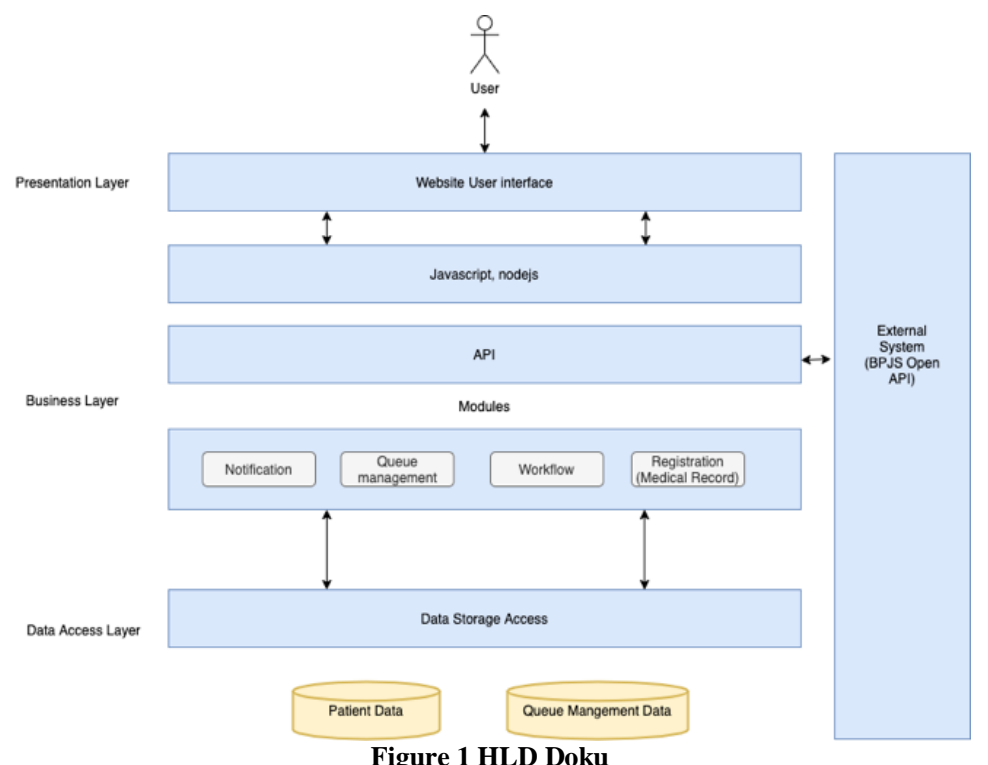

\subsection{Application Workflow}

Flowchart is a graphic description of the steps and sequence of procedures for using a document application.

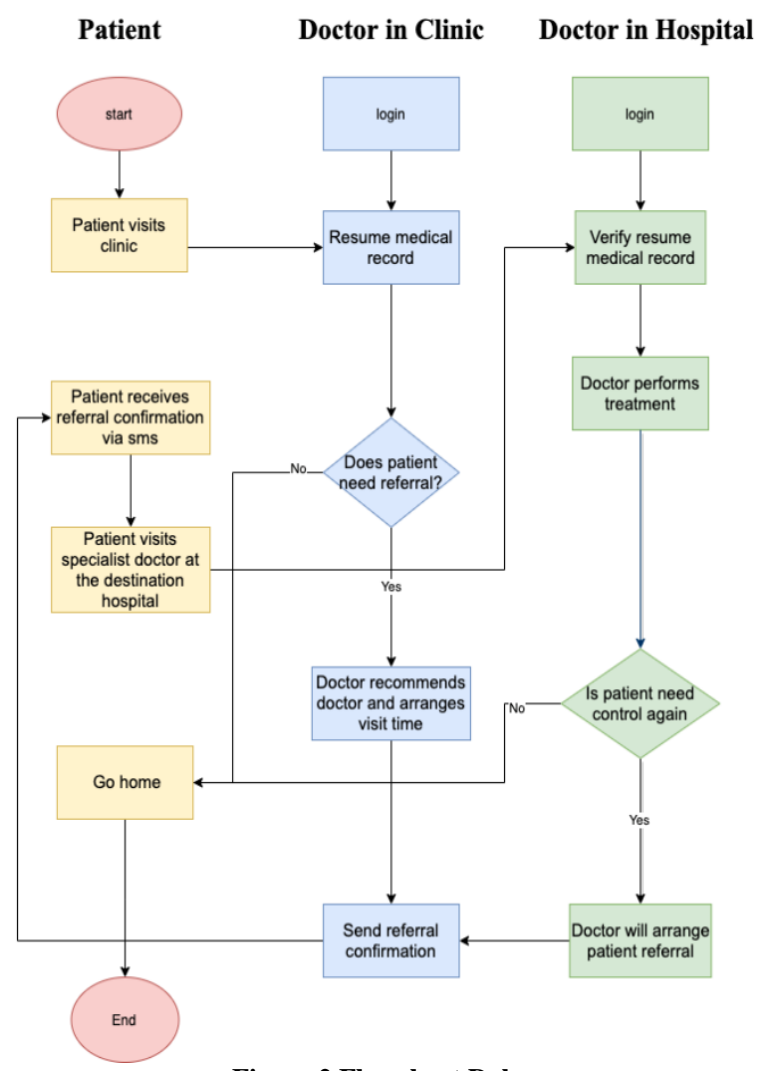

Figure 2 Flowchart Doku
Figure 2 Flowchart of Documents

Figure 2 is a description of the patient's procedure for getting services at a referral hospital in real time. The patient needs to visit the level one health facility for consultation first, then the health worker at the level one facility will decide whether the patient needs further treatment or not based on the results of the examination. If the patient receives a referral recommendation, the patient will be assisted by a doctor at a level 1 health facility to find the availability of the desired doctor. Then the doctor will schedule the patient's visit. After that the patient will receive a short message as a confirmation of the referral, the short message will detail the time of visit at the destination hospital.

Patient visits a level 2 health facility according to the time determined by the doctor of the health facility 1 . The patient can go directly to the doctor's room that has been determined. The patient will automatically enter the queue at the destination doctor, the patient just waits for the queue to come and his name is called. After the patient's name is called, the health 
facility 2 doctor gives action to the patient, after the action the doctor summarizes the patient's medical record and decides whether the patient needs a referral or not. If yes, the doctor of health facility 2 will schedule a return visit and the patient will receive a confirmation SMS.

\subsection{Supply Chain Management}

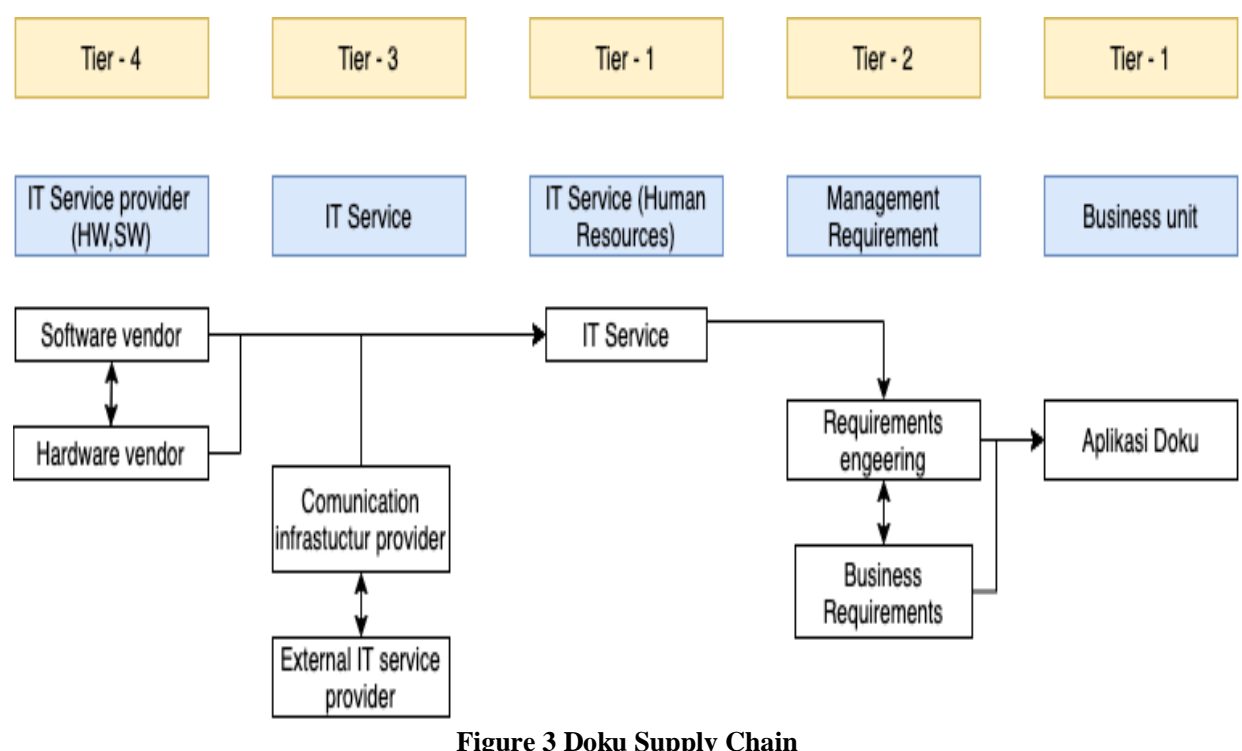

Figure 3 is a supply chain flow to build an application product. Doku means establishing partnerships with software vendor companies and hardware vendors. Finding a reliable vendor service where when the company needs it will get good service and products. Ensure human resources are in accordance with company needs.

\subsection{Quality Management}

Management also keeps the application minimal from bugs. The IT team, especially SQA, will be a group of customer representatives who will pay attention to the Doku application from the customer's point of view. Activities carried out by SQA review Doku product activities to verify process compliance, ensure Doku products are in accordance with the requirements that have been given by the product team. Record any incompatibility that exist in Doku and report to the developer team and coordinate control and management of changes that occur in the Doku document application. Ensure that all bugs findings and behavior changes are documented as material for evaluation of document product quality management. To keep application quality free from bugs.

\section{CONCLUSION}

This business opportunity is quite large, although there are threats from existing applications, with more brands and users, but based on the results of QSPM is product development strategy, Doku will always update features and add according to market needs. As well as maintaining network and application quality with minimal bugs.

\section{Acknowledgement: None}

\section{Conflict of Interest: None}

\section{Source of Funding: None}

\section{REFERENCES}

1. Robert M. Grant (2010). Contemporary Strategy Analysis. John Wley \& Sons Ltd.

2. Ul Haq, D., Harianto, \& Indradewa, R. (2020). Strategic Formulation Analysis of Virtual Gas Pipeline Business Development 
(CNG \& LNG). International Journal of Research and Review (Ijrrjournal.Com), 7(12). $57-65$

3. Taryana, T.Y. R. Syah, Fajarwati, D. \& Indradewa, R. (2021). Implementation of Operational Strategy Planning in Arena Corner Business. Journal of Multidisciplinary Academic, 5(2). 118- 123.

4. Ramadhan, R., T.Y.R. Syah, Indradewa, R., \& Fajarwati, D. (2020). Determination of Factory Location PT. Kelola Lingkungan Kita Using Factor Rating. Journal of Multidisciplinary Academic, 4(6). 435 438.
5. Hardono, A., T.Y.R. Syah, Indradewa, R., \& Krisnanto, A. (2021). Operational System Exclusive Funeral Muslim in Indonesia "Darul Muqamah Memorial Park." International Journal of Research and Review (Ijrrjournal.Com). 8(3). $679-686$.

6. Slack, Nigel. Lewis, Michael. Operations Strategy. (2013). Pearson Ltd.

How to cite this article: Handayani SR, Indradewa R, Syah TYR et.al. Implementation of operational strategy planning in doku application. International Journal of Research and Review. 2021; 8(8): 602-606. DOI: https://doi.org/10.52403/ijrr.20210880 